University of Nebraska - Lincoln

DigitalCommons@University of Nebraska - Lincoln

Papers in the Earth and Atmospheric Sciences

Earth and Atmospheric Sciences, Department

7-1906

\title{
A WORKABLE BED OF COAL IN NEBRASKA
}

Erwin Hinckley Barbour

University of Nebraska-Lincoln

Follow this and additional works at: https://digitalcommons.unl.edu/geosciencefacpub

Part of the Earth Sciences Commons

Barbour, Erwin Hinckley, "A WORKABLE BED OF COAL IN NEBRASKA" (1906). Papers in the Earth and Atmospheric Sciences. 354.

https://digitalcommons.unl.edu/geosciencefacpub/354

This Article is brought to you for free and open access by the Earth and Atmospheric Sciences, Department of at DigitalCommons@University of Nebraska - Lincoln. It has been accepted for inclusion in Papers in the Earth and Atmospheric Sciences by an authorized administrator of DigitalCommons@University of Nebraska - Lincoln. 
of a twenty-six-inch bed of workable coal, and five thousand for a thirty-six-inch bed, it is only within the past few days that any one has filed with the governor legitimate claims for the bounty. The bed of coal recently exposed, near Peru, Neb., extending some fortytwo feet along the sides of a tunnel back from the banks of Honey Creek, seems to be fully thirty-four inches in thickness, as measured by the writer. This is known as the Honey Creek or Peru coal mine. The seam is level and readily accessible; the mine, being ten feet above the creek, is easily drained and transportation is at hand. While the extent of the newly discovered bed is a matter of conjecture, the farms near and adjacent to the Peru coal bed are likewise underlaid probably with the same seam of coal, judging from scattered surface indications. It is reasonably certain that a resource of local interest will be developed, and for a time at least Nebraska may lose its distinction 'the state without a mine.' As to the quality of the coal, whether good or bad, matters little, for any coal is good in a state supposed to be destitute of natural fuel. Analyses of the Honey Creek coal made by Mr. L. J. Pepperberg, a fellow in the department of geology in the University of Nebraska are given in the table.

It must be remembered that the following analyses are made from samples which are

\begin{tabular}{|c|c|c|c|c|c|c|c|c|}
\hline$\cdot$ & 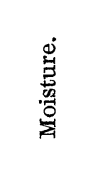 & 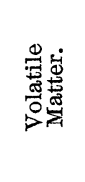 & 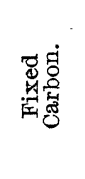 & gี & 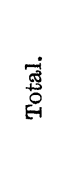 & 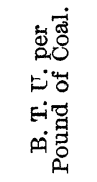 & 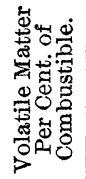 & 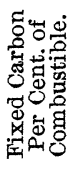 \\
\hline $\begin{array}{l}\text { Sample No. I., air.dried.................... } \\
\text { Sample No. II., water-soaked as mined.. } \\
\text { Sample No. III., lignitic coal, Cumber- } \\
\text { land, Wyo., for comparison..................... }\end{array}$ & $\begin{array}{l}10 \\
32.22 \\
3.65\end{array}$ & $\begin{array}{l}45.25 \\
28.54 \\
44.27\end{array}$ & $\begin{array}{l}36.28 \\
19.38\end{array}$ & $\begin{array}{r}8.47 \\
19.86\end{array}$ & $\begin{array}{l}100 \\
100\end{array}$ & $\begin{array}{r}12,621 \\
7,492 \\
14,100\end{array}$ & $\begin{array}{l}55.50 \\
54.80 \\
54.90\end{array}$ & $\begin{array}{l}44.50 \\
45.20\end{array}$ \\
\hline
\end{tabular}

A WORKABLE BED OF COAL IN NEBRASKA.

Aцtноugh for years past the state legislature of Nebraska has offered a bounty amounting to four thousand dollars for the discovery

Nights of September 23 and 24, 1896,' ScIence, N. S., 6, 409, September 10, 1897. close to the surface, badly weathered, therefore representing the worst rather than the best of this coal.

By the time the tunnel has been extended one hundred feet the overlying shales will be about fifty feet in thickness and the coal will presumably be of better quality. Across the 
valley of the Missouri in Iowa a bed of coal, similar in all respects to this one, occurs, and is probably a part of the same bed. The evidence from deep wells at Omaha, Nebraska City, Beatrice and Lincoln, the last named well being 2,463 feet deep, points to beds of coal but a few inches in thickness and thinning rapidly to the westward.

For a number of years coal has been mined in various places in the southeastern, or carboniferous portion of this state, as at Nebraska City, Rulo, South Fork and elsewhere, but the thickness of coal in each case scarcely equaled eighteen inches and there was no profit in mining such coal. The best efforts of a Lincoln company headed by Mr. Bullock, a man of ability and experience, failed to make the mine at Rulo profitable, and the undertaking, like that of others, was abandoned at the end of two years as unprofitable.

Although considerable amounts of coal were furnished at one time by the South Fork Mine to the neighboring towns, Table Rock, Humboldt, Salem, Dawson and Seneca, the bulk of coal mined thus far has been used by those mining it. Farmers and others often dig out their own supply of winter fuel. A vigorous effort was made to develop a bed, said to be eighteen inches thick, in northeastern Nebraska, it being a lignitic coal in the Cretaceous and in no way related to the coal recently discovered. Simultaneously with the discovery of coal at Peru come reports not yet verified of a bed equally thick at Falls City. It has certainly been the opinion of geologists at large that commercial coal was not to be expected in Nebraska, and the occurrence of a workable bed in Peru does not materially change this opinion, for at the best it must be local, as shown by surrounding deep wells. Though limited to a square mile or so it is of importance to this commonwealth.

The owner of the land on which the bed of coal was found leased the mine at the rate of fifty cents on every ton of coal sold for three dollars, and one dollar on every ton sold at four dollars, which may be an item of interest to those regularly engaged in mining.

ERWIN H. BarboUr.

The University of Nebraska, Lincoln, April 5, 1906. 